\title{
Markkina, verkosto ja hierarkia kapitalistisessa markkinataloudessa
}

\section{Raimo Lovio}

Markkinat-termiä käytetään hyvin monessa mielessä. Yleisimmässä merkityksessä se on metafora ajatukselle, että taloudelliset päätökset tehdään tai tulisi tehdä ottaen huomioon vain välittömät taloudelliset kustannukset ja hyödyt. Hieman tarkemmassa merkityksessä markkinataloustermiä on käytetty kapitalismin synonyymina. Kummassakaan tapauksessa ei sanota vielä mitään siitä miten markkinat, markkinamekanismi tai markkinavoimat konkreettisesti toimivat: millaisen institutionaalisen systeemin markkinat muodostavat?

Tässä kirjoituksessa tarkastelen markkinoita tästä konkreettisesta institutionaalisesta näkökulmasta käsin. Käsitteitä ja näkökulmia tarkentamalla pyrin osoittamaan, että markkinat näyttelevät Suomessa ja Suomen kaltaisissa maissa vähäisempää roolia kuin yleensä otaksutaan.

\section{Kapitalistinen markkinatalous, kilpailu ja valtio}

Aloittakaamme käsitteestä markkinatalous. Vaikuttaisi järkevältä luonnehtia tällä käsitteellä talousjärjestelmää, jossa hallitseva osa tuotteista tuotetaan vaihtoa varten. Käsitteen vastakohta on omavaraistalous. Markkinataloudessa kulutusyksiköt ostavat tuotteita ja voidakseen ostaa tuotteita ne myyvät työvoimaansa. Vastaavasti tuotantoyksiköt ostavat tuotannontekijöitä ja myyvät tuotteita.

On mielenkiintoinen taloushistoriallinen kysymys milloin Suomesta tuli markkinatalousmaa. Tai tarkemmin sanottuna: mielenkiintoista on se kuinka pitkän ajan markkinatalouden vahvistuminen on vienyt. 60-luvun "Suuri muutto" oli luultavasti viimeinen suuri omavaraistaloutta murentanut tekijä, mutta ei tämä prosessi ole vieläkään päättynyt.

Markkinatalouksia voi olla monenlaisia. Kapitalistisia markkinatalouksia luonnehtivat yksityinen yrittäjyys ja keskeisten tuotantovälineiden yksityisomistus. Tuotannon tavoitteena on tuottaa siihen sijoitetulle pääomalle mah- dollisimman korkea tuotto. Kysyntä ja tarjonta ohjaavat eri tavaroiden tuotannon määriä eikä keskitetty suunnittelu.

Kapitalistiseen markkinatalouteen liitetään usein myös ajatus vapaasta kilpailusta, jonka sanotaan tuottavan kansantalouden kannalta tehokkaita tuloksia. Tämä käsitys on kuitenkin erityisen epämääräinen, osin varmaan tarkoituksellisesti.

Vapaa kilpailu ei tarkoita sitä, että yritykset kaikin keinoin pyrkisivät suoraan ja avoimeen kilpailuun. Pikemminkin se tarkoittaa yritysten kilpailua siitä, miten ne pyrkivät välttämäään suoran kilpailun. Kuten kaikki yritysten johtamista koskevat kirjat neuvovat yritykset pyrkivät aina asemoimaan itsensä niin, että ne mahdollisimman hyvin välttyvät suoralta kilpailulta. Perusoppikirjat kertovat myös, että toimialojen elinkaaren alkuvaiheessa vallitsee yleensä innovoivien yritysten hallitsema oligopolistinen tilanne ja toimialan kypsyessä keskittymisprosessin seurauksena hallitsevien yritysten oligopolistinen tilanne. Oligopolistinen asetelma on kaikkein tyypillisin kilpailutilanne.

Ei myőskään ole aina selvää, että voimakas suora kilpailu tuottaa tehokkaimmat ratkaisut. Joseph Schumpeterin tunnetun käsityksen mukaan dynaamisessa kilpailussa monopoleista voi olla etua: ne uskaltavat sijoittaa teknologiseen kehitystyöhön, koska tietävät myös hyötyvänsä siitä. "There is no more of paradox in this than there is in saying that motorcars are travelling faster than they otherwise would because they are provided with brakes" (Schumpeter 1942, 88).

Valtio on jopa tukenut innovoivan yrityksen asemaa patenttijärjestelmällä, jonka avulla yritys voi suojautua useiksi vuosiksi keksintönsä kopiointia vastaan. Tämä valtiointervention tapaus on esimerkki ns. market failure -tilanteesta, jossa nimenomaisesti on katsottu, ettei markkinamekanismi tuota kansantalouden kannalta optimaalisia tuloksia. Ympäristökysymykset on 
toinen tunnettu esimerkki.

Ympäristöongelmat ovat nostaneet esiin uusia valtiointervention muotoja. On tapana erottaa markkinaohjaus ja normiohjaus. Esimerkiksi kun valtio asettaa yksittäiselle tehtaalle yksiselitteisen ylimmän päästörajan puhutaan normiohjauksesta, mutta jos valtio asettaa haittaveron puhutaan markkinaohjauksesta. Molemmissa tapauksissa on kysymys poliittiseen päätöksentekoon perustuvasta ohjauksesta, ei markkinatalouden autonomisesta reagoinnista.

\section{Markkina, hierarkia ja verkosto yritysten vaih- toehtoina}

Puhe market failure -tapauksista voi synnyttää sellaisen mielikuvan, että näitä poikkeustapauksia lukuunottamatta yritysten toimintaa koordinoidaan ja organisoidaan nykyisissä kapitalistisissa markkinatalousmaissa vain markkinainstituution kautta. Tällainen käsitys on kuitenkin harhaanjohtava ja virheellinen. Yritystoimintaa koordinoidaan ja organisoidaan kolmen institutionaalisen muodon kautta. Nämä ovat markkina (vaihto), hierarkia ja verkosto.

Syksyllä 1991 taloustieteen Nobel-palkinnon saanut englantilainen Ronald Coase esitti vuonna 1937 ilmestyneessä artikkelissaan "The Nature of the Firm" kysymyksen, miksi markkinatalouksissa tarvitaan ylipäänsä yrityksiä? Miksei koko taloudellista toimintaa ole organisoitu yhdessä yrityksessä? Hän oli kiinnostunut siitä, mikä määrittää yritysten väliset rajat. Yritysten olemassaolon ja niiden välisten rajojen selittämiseksi hän kehitti ajatuksen liiketoimikustannuksista eli transaktiokustannuksista. Liiketoimikustannuksia on kahta lajia: hierarkiakustannuksia ja vaihtokustannuksia. Yritysten sisällä tapahtuvan toiminnan organisointi synnyttää hierarkiakustannuksia, kun taas markkinoilla toimiminen synnyttää vaihtokustannuksia. Coasen ajatus oli, että yritykset vetävät oman hierarkiansa puitteisiin taloudellista toimintaa siihen asti kunnes hierarkiakustannukset ylittävät vaihtokustannukset (varsinaiset tuotantokustannukset molemmissa mukaan laskien). Coasen ajatusta on sittemin kehittänyt O. E. Williamson $(1975,1985)$.

Kokemus on osoittanut, että hierarkiakustannukset ovat yllättävän alhaiset markkinaoperaatioiden aiheuttamiin kustannuksiin nähden. Lähes kaikissa kapitalistisissa markkinatalousmaissa yritystoimintaa hallitsevat nykyisin vertikaalisesti ja horisontaalisesti diversifioituneet suuret monialayhtymät. Alvin Chandlerin (1977) ilmaisua käyttäen konsernien sisäisten hierarkioiden näkyvät kädet ovat suurelta osin täydentämässä markkinoiden näkymätöntä kättä. Suuri osa talouden koordinoinnista, liiketoimien suunnittelusta ja toteutuksesta sekä myös kaupasta tapahtuu nykyisin suurten konsernien enemmän tai vähemmän suunnitelmallisesti toimivien hierarkioiden sisällä. Suomessa noin 10-15 monialakonsernia hallitsee teollisuuden jalostusarvosta, viennistä sekä tutkimus-ja kehitystoiminnasta noin puolta. Tämä tarkoittaa myös sitä, että yritysten sisäinen hierarkia on varsin keskeinen taloudellisen toiminnan koordinoinnin institutionaalinen muoto markkinoiden ohella.

Toinen englantilainen taloustietelijä, G. B. Richardson, esitti artikkelissaan "The Organisation of Industry" (1972) Coasen näkemyksen siten, että ns. markkinatalousmaiden talous ei ole puhdas markkinoiden aava ulappa, joka aaltoilee spontaanin hintamekanismin tahdissa, vaan tällä merellä on paljon suuria ja pieniä saaria, yrityksiä, joiden toimintaa koordinoidaan suunnitelmallisesti. Markkinatalous ei ole ulappa vaan saaristo.

Richardson totesi kuitenkin edelleen, että saaristomielikuva on puutteellinen. Hän totesi, että yritysten välillä on todellisuudessa paljon sellaisia yhteistyö- ja riippuvuussuhteita, joita ei ole syytä kutsua markkinasuhteiksi. Näitä ovat esimerkiksi pitkäaikaiset alihankintasuh- 
teet yritysten välillä sekä yhteisprojektit tutkimus- ja kehitystoiminnan tai markkinoinnin alueella. Mielikuvaa jatkaakseni: saarien välille on rakennettu siltoja ja perustettu säännöllisiä laivareittejä.

Tällaisia markkina- ja hierarkiasuhteiden välissä olevia suhteita on nykyisin kutsuttu verkostosuhteiksi. Erotukseksi puhtaista markkinasuhteista (vaihtosuhteista) verkostosuhteille on tyypillistä pitkäaikaisuus, tehokkaan yhteistoiminnan mahdollistava informaation vaihto sekä verkostoon osallistuvien teknisten ja kaupallisten toimien yhteensovittaminen. Kun yritys hankkii jonkin tarvitsemansa komponentin ostamalla sen tukkukaupasta, kyseessä on puhdas markkinaratkaisu (vaihtosuhde), mutta kun yritys ryhtyy pitkäaikaiseen luottamukselliseen yhteistyöhön jonkin alihankkijan kanssa näiden komponenttien kehittämiseksi ja tuottamiseksi, on kysymys verkostosuhteesta.

Verkostosuhteita syntyy kahdesta suunnasta: toisaalta yritysten välisiä markkinasuhteita kehitetään verkostosuhteiksi ja toisaalta yritysten sisäisiä hierarkiasuhteita puretaan verkkomaisiksi ratkaisuiksi. Jälkimmäisestä on tyypillinen esimerkki sellainen, jossa aikaisempi suuri yhtenäinen konserni puretaan joukoksi erillisiä yhtiöitä, tytäryrityksiä ja tulosyksiköitä. Yrityksen itsenäistyvät osat käyvät kauppaa keskenään, ja ne voidaan myös oikeuttaa tarjoamaan ja ostamaan palveluja oman konsernin ulkopuolelta. Lopputulos on, että aiemmin hyvin selvät yritysten sisäiset hierarkkiset organisaatiot ja toisaalta yritysten väliset rajat hämärtyvät. Hierarkioiden ja markkinoiden välinen selkeä viiva liudentuu tai ainakin peittyy verkkojen alle. On hyvin vaikea sanoa, mistä jokin suuryritys alkaa ja mihin se päättyy.

Markkinoiden, hierarkian ja verkostojen merkitys vaihtelee

Valitessaan liiketoimintojensa institutionaali- sia muotoja yrityksillä on siis aina olemassa kolme vaihtoehtoa. Ne voivat suorittaa osan liiketoimistaan oman hierarkiansa sisällä, osan ne voivat toteuttaa markkinoiden kautta, ja osan yhteistoiminnallisten verkostojen kautta. Valintaan vaikuttavat sekä kansalliset olosuhteet että talouden kehitysvaihe.

Richard Whitley (esim. 1991) on osoittanut, että ns. markkinatalousmaiden välillä on huomattavia eroja markkinoiden, hierarkioiden ja verkostojen keskinäisessä merkityksessä. Nämä erot heijastavat eroja maiden historiallisesti muovautuneissa talouden ja kulttuurin rakenteissa (valtion rooli, rahoitusinstituutiot, koulutusjärjestelmä, työmarkkinat jne.). On olemassa suurten yritysten hallitsemia hierarkiamaita (esimerkiksi Ruotsi) ja pienyritysvaltaisia maita (esimerkiksi Tanska). On olemassa paljon verkostosuhteita hyödyntäviä maita (esim. Japanin keiretsu-organisaatio) ja maita, joissa ei ole suosittu yritysten yhteistoimintaa (esimerkiksi kilpailulainsäädännön rajoitukset Yhdysvalloissa).

Suomen markkinatalous ei nojaa liiketoimien koordinoinnissa kovin vahvasti markkinoihin. Suomen teollistamisessa valtiolla on ollut vahva välitön rooli. Suomen pankkijärjestelmä on ollut äärimmäisen keskittynyt ja luotonsaanti on ollut voimakkaasti säänneltyä. Suomen teollisuutta ovat hallinneet pääomavaltaisten teollisuusalojen suuryritykset, jotka ovat voimakkaasti diversifioituneet myös uusille kasvualoille. Markkinoiden ohi kulkevia yritysten yhteistyöverkostoja ei Suomessa ole rajoitettu tehokkaalla kilpailulainsäädännöllä. Toisin sanoen hierarkkisiin ja verkostosuhteisiin on nojauduttu varsin paljon liiketoimien koordinoinnissa puhtaan markkinamekanismin sijasta ja ohella (vrt. Lilja, Räsänen \& Tainio 1992).

Myös ajallisesti markkinoiden, hierarkioiden ja verkostojen välinen keskinäinen merkitys vaihtelee. Yksinkertaistavasti on usein esitetty, että fordismin kultakauteen liittyi hierar- 
kia-ja markkinasuhteiden korostuminen. Suuret yritykset pyrkivät tekemään kaiken itse ja satunnaisia alihankkijoita pidettiin varpaisillaan kilpailuttamalla niitä keskenään jatkuvasti. Postfordismin kaudella verkostosuhteiden on taas katsottu kasvattaneen merkitystään: alihankinta, yhteistyö ja konsernien päätöksenteon hajauttaminen ovat olleet vahvasti esillä (vrt. Lovio 1989, Ollus ym. 1990).

Verkostosuhteita syntyy, koska yritysten välinen suora informaation vaihto ja yhteistoiminta ovat monissa tapauksissa niiden kannalta tehokkaampia tapoja toimia kuin toiminnan koordinointi markkinoiden kautta. Itse asiassa tällä hetkellä verkostojen ja ns. strategisten allianssien rakentaminen on liikkeenjohtokirjallisuuden ja -konsultoinnin aktiivisimmin suosittelemia keinoja. Yrityksiä kehotetaan luopumaan lyhytaikaisista markkinasuhteista alihankinnoissa ja pyrkimään pitkäaikaiseen yhteistyöhön parhaimpien yritysten kanssa. Yrityksiä patistetaan yhteisiin tutkimusprojekteihin jne. (ks. esim. Networks of Innovators...).

Kattavaa empiiristä analyysia verkostosuhteiden merkityksen kasvusta esimerkiksi Suomessa viimeisen kymmenen vuoden aikana ei ole olemassa (suppea kuvaus Ylä-Anttila \& Lovio 1990). Tiedetään, että suuret konsernit ovat yhtiöittäneet paljon toimintojaan. Alihankintojen määrä on lisääntynyt ja japanilaisia osahankinnan malleja on ainakin yritetty tuoda Suomeen. Yritysten tutkimusyhteistyö on lisääntynyt Teknologian kehittämiskeskuksen, Eurekan jaEY:n tutkimusohjelmien takia. Tarkkaa analyysia näiden ilmiöiden laajuudesta ja laadullisesta merkityksestä yritystoiminnalle ei kuitenkaan ole tehty.

Verkostoajattelua ei ole hyväksytty sellaisenaan sen paremmin kirjallisuudessa kuin käytännön sovelluksissakaan. Yritysjohdon näkökulmasta keskeisin kritiikki on esitetty näin: Johtaako verkostomallin hyödyntäminen siihen, että yrityksen pitkän aikavälin edut uhra- taan lyhyen aikavälin eduille? Jos yritys hajautetaan pieniksi erillisiksi yksiköiksi, niin kuka hoitaa yrityksen yleiset edut? Jos kaikki yksiköt toimivat lyhyen aikavälin tulostavoitteet mielessä, niin kuka investoi pitkän aikavälin kehitystyöhön? Pelko on siis, että verkostomallissa konsernipuun oksat ja lehvästöt saadaan hyvään kuntoon lyhyeksi ajaksi, mutta samaan aikaan juuret jäävät hoitamatta (Prahalad \& Hamel 1990).

Ammattiyhdistysliikkeen näkökulmasta verkostomallia on arvosteltu lähinnä siitä, että se voi tuoda mukanaan lisääntyvää epävarmuutta. Joustavat, nopeasti muuttuvat organisaatioratkaisut sekä konsernin ylimmän johdon jatkuva portfoliopeli luovat tilanteen, jossa varsinkin heikoimmilla resursseilla varustetut työntekijät kokevat joutuvansa pelinappulan asemaan. Ammattiyhdistysliike vastustaa useimmiten hierarkiaratkaisuista verkosto- tai markkinaratkaisuihin siirtymistä. Kun yritykset tai julkinen sektori lisäävät "talon ulkopuolisia" hankintoja ovat "talon sisällä" aikaisemmin näitä tehtäviä hoitaneet vaikeassa asemassa ainakin siirtymävaiheessa.

Kilpailupolitiikan näkökulmasta verkostosuhteiden on taas arveltu olevan vain uusi nimi vanhalle kartellipolitiikalle. Pelätään, että yritysten välinen selkeä markkinakilpailu vähenee lisääntyvän verkostoitumisen oloissa.

Käsittääkseni tällaisella kritiikillä on perusteita. Verkostosuhteet eivät ole ratkaisu kaikkiin organisointiongelmiin ja verkostosuhteita voi olla hyvin monenlaisia. Verkostosuhteet eivät ole myöskään mikään yleinen 'kolmannen tien" malli, vaikka markkinoiden sokeaan käteen ja hierarkian käskevään käteen verrattuna verkostojen yhdistävä käsi onkin miellyttävän pehmeä vaihtoehto.

Tärkeää on kuitenkin muistaa, että verkostovaihtoehtokin on olemassa ja käytössä. Kapitalismi ei perustu puhtaisiin markkinoihin läheskään niin paljon kuin yleensä kuvitellaan. 


\section{Kirjallisuus}

Chandler, A. D.: The Visible Hand: The Managerial Revolution in American Business. Belknass Press of Harvard University Press, Cambridge, Mass. 1977.

Coase, Ronald: The Nature of the Firm, Economica 1937: 386-405. Lyhentaien julkaistu Putterman, L.: The Economic Nature of the Firm. Cambridge University Press 1986.

Lilja, K., Räsänen, K. \& Tainio, R.: Sectoral foundations of competitive advantage: the case of Finnish forest corporations. Julkaistaan kirjassa Whitley, R.(ed.):SocialFoundations of Enterprise:Europe in Comparative Perspective. Sage, London 1992.

Lovio, R.: Suomalainen menestystarina? - tietoteollisen verkostotalouden läpimurto. Hanki ja jää, Helsinki 1989.

Networks of Innovators, Montreal Workshop, 1-3 May 1990. Aineisto julkaistu Research Policy -lehden teemanumerona 5, 1991.
Ollus, M. ym.: Joustava tuotanto ja verkostotalous. Tekniikan, talouden ja yhteiskunnan vuorovaikutus 1990-luvulla. SITRA 109, Helsinki 1990.

Prahalad, C. K. \& Hamel, G.: The core competence of the corporation. Harvard Business Review, May-June 1990.

Richardson, G. B.: The Organisation of Industry. Economic Journal 1972: 883-896.

Schumpeter, J. A.: Capitalism, Socialism, and Democracy. New York 1942.

Whitley, R.: The Social Construction of Business Systems in East Asia. Organization Studies 1991: 1-28.

Williamson, O.E.: Markets and Hierarchies: Analysis and Industry Implications. Free Press, New York 1975.

Williamson, O. E.: The Economic Institutions of $\mathrm{Ca}$ pitalism. Basic Books, New York 1985.

Ylä-Anttila, P. \& Lovio, R.: Flexible production, industrial networks and company structure some scandinavian evidence. ETLA Keskusteluaiheita 338, Helsinki 1990. 